\title{
Glucagon-like peptide-1 analogues - an efficient therapeutic option for the severe insulin resistance of lipodystrophic syndromes: two case reports
}

\author{
Joana Oliveira ${ }^{1,2^{*}}$, Eva Lau ${ }^{1,2}$, Davide Carvalho ${ }^{1,2}$ and Paula Freitas ${ }^{1,2}$
}

\begin{abstract}
Background: Lipodystrophic syndromes are uncommon medical conditions which are normally associated with metabolic disorders, such as diabetes mellitus, dyslipidemia, and fatty liver disease. These complications are generally difficult to treat, particularly diabetes, due to severe insulin resistance. We present two case reports of successful treatment of diabetes with glucagon-like peptide-1 analogues in patients with clinical features of lipodystrophic syndromes.

Case presentation: Two white women aged 49 and 60 years manifested marked central body fat deposition with severe lipoatrophy of their limbs and buttocks and pronounced acanthosis nigricans. They had hypertension, dyslipidemia, fatty liver disease, and poorly controlled diabetes (glycated hemoglobin 8.3\% and 10.2\%, respectively) despite the use of three classes of oral antidiabetic drugs taken in combination in the first case, and high doses of insulin in the second case. Four months after the addition of glucagon-like peptide-1 analogue to their previous treatment they both showed a pronounced improvement in metabolic control (glycated hemoglobin 5.6\% and $6.2 \%$, respectively). In the first case, a weight loss of nearly $30 \mathrm{~kg}$ was recorded.
\end{abstract}

Conclusions: We intend to demonstrate that glucagon-like peptide-1 analogues could be a valuable tool for patients with lipodystrophic disorders, probably by improving body fat distribution, with favorable results in insulin-sensitivity and glycemic control.

Keywords: Lipodystrophy, Diabetes mellitus, GLP-1 analogues

\section{Background}

Lipodystrophic syndromes are rare disorders characterized by selective loss of adipose tissue, mainly from subcutaneous compartments. Lipoatrophy may vary from being partial, co-existing with adipose tissue depots in ectopic sites, to generalized [1]. These syndromes are usually linked with severe metabolic complications, such as insulin resistance, diabetes mellitus, dyslipidemia, hepatic steatosis, and hypertension [2, 3]. Loss of adipose tissue seems to give rise to both lipodystrophy and metabolic disorders [2], which suggests that it is

\footnotetext{
*Correspondence: joana.ij.oliveira@gmail.com

'Department of Endocrinology, Diabetes and Metabolism, Centro Hospitalar

São João, Alameda Prof. Hernâni Monteiro, 4200 Porto, Portugal

${ }^{2}$ Faculty of Medicine, University of Porto, Porto, Portugal
}

the absence of fat tissue and the consequent leptin deficiency that leads to insulin resistance $[4,5]$. Furthermore, adipocytes provide a benign location to accumulate lipids and, thus, when they are absent, lipids will store in the liver, muscle, and ectopic tissues, causing significant metabolic complications [6]. Patients may present acanthosis nigricans, acromegaloid features, muscular hypertrophy, and hirsutism in the context of ovarian hyperandrogenism: polycystic ovary syndrome (PCOS) $[2,7]$. Over the last decades, several causative genetic mutations have been identified in patients with lipodystrophies. Nevertheless, lipodystrophy is a clinical diagnosis which is based on a physical examination, and many such patients present no mutations of identified genes, suggesting 
that other genes are involved and have not yet been deciphered [8]. The treatment of complications involves classical intervention strategies, however, owing to the severity of insulin resistance, managing such complications can be challenging. Glucagon-like peptide-1 (GLP-1) analogues stimulate glucose-dependent insulin secretion and suppress inappropriately elevated glucagon secretion, thus improving glucose homeostasis. These analogues also delay gastric emptying and act centrally to promote satiety, thus reducing food intake, which leads to weight loss. This loss seems to result from a reduction in fat mass, rather than lean tissue mass [9], with a preferential decrease in visceral fat [10]. We describe two clinical cases of diabetes in patients with lipodystrophic features who were successfully treated with GLP-1 analogues.

\section{Case presentation \\ Case 1}

A 49-year-old white woman was referred to our Endocrinology department for obesity. She presented diabetes treated with metformin $2500 \mathrm{mg} /$ day, sitagliptin $100 \mathrm{mg} /$ day, and gliclazide $120 \mathrm{mg} /$ day. She had hypertension, dyslipidemia, hyperuricemia, fatty liver disease, and obstructive sleep apnea. Furthermore, she was being treated for a major depression, partly motivated by body image problems. She weighed $89.5 \mathrm{~kg}$, had a body mass index (BMI) of $33.7 \mathrm{~kg} / \mathrm{m}^{2}$, and presented an evident abdominal fat deposition (waist circumference $123 \mathrm{~cm}$ ), with markedly reduced adipose tissue in her limbs and buttocks. She had a round face with cervical acanthosis nigricans, and an accumulation of fat in the chin and in the cervicodorsal and supraclavicular regions. Laboratory tests revealed glycated hemoglobin (A1c) 8.3\%; total cholesterol $273 \mathrm{mg} / \mathrm{dL}(<200)$, high-density lipoprotein (HDL) cholesterol $49 \mathrm{mg} / \mathrm{dL}(>60)$, low-density lipoprotein (LDL) cholesterol $196 \mathrm{mg} / \mathrm{dL}(<130)$, triglycerides $350 \mathrm{mg} / \mathrm{dL}(<150)$, under statin; and uric acid $6.9 \mathrm{mg} /$ $\mathrm{dL}$ (2.3 to 6.1$)$. She presented normal 24-hour urinary free cortisol of $39 \mathrm{mcg} / 24$ hours (36 to 137) and an overnight dexamethasone suppression test recorded a serum cortisol of $0.4 \mathrm{mcg} / \mathrm{dL} \quad(<1.8 \mathrm{mcg} / \mathrm{dL})$. She started taking exenatide $2 \mathrm{mg}$ once a week, with good tolerance. Sitagliptin was suspended, while maintaining the other antidiabetic drugs. After 4 months of therapy, she lost $29.2 \mathrm{~kg}$ (approximately 33\% of her initial body weight) and her A1c was $5.6 \%$. The results of genetic tests for mutations in LMNA gene and PPAR-gamma gene were negative.

\section{Case 2}

A 60-year-old white woman was observed in our Endocrinology department for diabetes. She presented hypertension, dyslipidemia, fatty liver disease, severe obstructive sleep apnea, depressive disorder, and a history of a previous ischemic stroke. She had poor glycemic control, with A1c values between 9 and $11 \%$ over recent years, requiring several medication adjustments. She was treated with metformin $2000 \mathrm{mg} /$ day, and a total daily dose of insulin of nearly 240 units in a basal-bolus regimen. Her regimen was: neutral protamine Hagedorn $(\mathrm{NPH})$ insulin three times daily (60 units in the morning, 50 units at lunch, and 46 units at night); insulin aspart at mealtimes (21 units at breakfast, 24 units at lunch, 11 units at afternoon snack, and 27 units at dinner); and a correctional insulin dose was added, based on her pre-prandial glucose value, resembling a sliding scale. Her insulin sensitivity factor was 10 . Her physical examination revealed that she was overweight (weight $75.9 \mathrm{~kg}$, BMI $33.7 \mathrm{~kg} / \mathrm{m}^{2}$ ), with central body fat deposition (waist circumference $105 \mathrm{~cm}$ ) and prominent lipoatrophy of her limbs and buttocks. She presented pronounced cervical and axillary acanthosis nigricans, and hirsutism. Laboratory tests showed an A1c of $10.2 \%$ and dyslipidemia: total cholesterol $226 \mathrm{mg} / \mathrm{dL}$ $(<200)$, HDL cholesterol $51 \mathrm{mg} / \mathrm{dL}(>60)$, LDL cholesterol $131 \mathrm{mg} / \mathrm{dL} \quad(<130)$, triglycerides $221 \mathrm{mg} / \mathrm{dL}$ $(<150)$, despite being medicated with statin. She had mildly elevated liver enzymes levels: aspartate aminotransferase $67 \mathrm{U} / \mathrm{L}$ (10 to 31), alanine aminotransferase $76 \mathrm{U} / \mathrm{L}$ (10 to 31), gamma glutamyl transferase $321 \mathrm{U} / \mathrm{L}$ (7 to 32 ), and alkaline phosphatase $175 \mathrm{U} / \mathrm{L}$ (30 to 120). Her renal function was normal. Cushing syndrome had been excluded: 24-hour urinary free cortisol $80.1 \mathrm{mcg} /$ 24 hours (36 to 137). An overnight dexamethasone suppression test registered serum cortisol of $0.8 \mathrm{mcg} / \mathrm{dL}$ $(<1.8 \mathrm{mcg} / \mathrm{dL})$. Treatment with liraglutide was initiated, in addition to insulin therapy, at $0.6 \mathrm{mg}$ every day for a week, titrated to $1.2 \mathrm{mg}$ for the next week, and then to $1.8 \mathrm{mg}$ daily. An insulin dose reduction of 20 units was recommended at the time that treatment with liraglutide was initiated. She reported no side effects, such as nausea, vomiting, diarrhea, or hypoglycemia. After 3 months of therapy, a total daily insulin dose of 200 units, metformin $2000 \mathrm{mg} /$ day, and liraglutide $1.8 \mathrm{mg}$ daily resulted in a much improved glycemic control (A1c $6.2 \%)$. She lost $1.8 \mathrm{~kg}$. Similarly, the results of genetic tests for mutations in LMNA gene and PPAR-gamma gene were negative.

\section{Conclusions}

A remarkable feature of lipodystrophic syndromes is the clinical heterogeneity regarding the extent and location of adipose tissue loss. Nevertheless, with very few exceptions, the majority of lipodystrophy disorders are associated with impaired insulin sensitivity and diabetes [8], which are complications that are difficult to treat with 
classical therapeutic options. In the two cases described, diabetes was successfully treated with the addition of a GLP-1 analogue to the previous therapeutic regimen. GLP-1 receptors (GLP-1R) are expressed in the arcuate and paraventricular nucleus of the hypothalamus, and recent evidence indicated that activation of arcuate GLP-1R sensitizes the liver to insulin and reinforces insulin action to suppress endogenous glucose production [11]. Furthermore, GLP-1 analogues seem to amplify insulin signaling in adipocytes by upregulating insulin signaling molecules. Liraglutide has been shown to ameliorate insulin resistance through upregulation of glucose transporter- 4 and to decrease oxidative stress and inflammation. It has also been shown to improve endothelial and cardiac function, which might result in increasing systemic insulin sensitivity [12]. Data from studies in diabetic rats showed that exenatide inhibits hepatic gluconeogenesis and increases glucose uptake in the peripheral skeletal muscle with improvement of hepatic and extrahepatic insulin resistance [13]. According to some studies, these drugs significantly influence fat distribution, and even a short course of treatment results in a significant decrease of subcutaneous and visceral fat deposits $[10,14]$. The effect starts showing shortly after the beginning of treatment $[9,15]$. The extent of weight reduction is not always as significant as that of the result described in the first case, but it has been shown that important health benefits can be achieved with modest weight loss [10]. For patients taking insulin, the addition of GLP-1 analogue may help offset weight gain, or even promote some weight loss and reduce insulin needs, with an improvement in glycemic control [16]. In fact, in our second case, there was a small reduction in weight, although the patient achieved target levels of A1c with lower insulin requirements. The potential predictors of different weight loss response with GLP-1 analogues treatment remain unidentified. A study evaluating the impact of genetic variability of GLP-1R on weight response to liraglutide demonstrated that some polymorphisms are associated with individual differences regarding weight loss response in obese women with PCOS. Thus, as GLP-1R is a major target for the GLP-1 analogues, its genetic variability could be hypothetically linked with the different response to the weight-reducing potential of these drugs in a clinically homogenous population [17].

As far as we know, our cases are the first reports of the treatment of patients with lipodystrophic syndromes not human immunodeficiency vírus (HIV)-associated, with severe insulin resistance, with GLP-1 analogues. We intend to demonstrate that GLP-1 analogues could be used as new tools for the treatment of these metabolic and adipose tissue disorders, reducing fat mass and insulin resistance, decreasing insulin requirements, and improving A1c.

\section{Abbreviations}

A1c: Glycated hemoglobin; BMI: Body mass index; GLP-1: Glucagon-like peptide-1; GLP-1R: GLP-1 receptors; HDL: High-density lipoprotein; HIV: Human Immunodeficiency Vírus; LDL: Low-density lipoprotein; PCOS: Polycystic ovary syndrome

\section{Acknowledgements}

None.

\section{Funding}

We declare that no funding has been received for this study.

Availability of data and materials

All data generated or analyzed during this study are included in this published paper.

\section{Authors' contributions}

$J O$ and EL collected the data, JO drafted the manuscript, and PF and DC critically reviewed it for important intellectual content. All the authors read and approved the final manuscript.

\section{Competing interests}

The authors declare that they have no competing interests.

\section{Consent for publication}

Written informed consent was obtained from the patients for publication of this case report and any accompanying images. A copy of the written consent is available for review by the Editor-in-Chief of this journal.

\section{Ethics approval and consent to participate}

Our Institutional Review Board approved the search of electronic medical records for this paper. The patients involved gave consent for the use of their medical records.

Received: 22 September 2016 Accepted: 11 December 2016 Published online: 13 January 2017

\section{References}

1. Fardet L, Vigourox C, Capeau J. Syndromes lipodystrophiques. Rev Med Interne. 2013;34(10):614-22.

2. Vatier C, Bidault G, Briand N, Guénantin AC, Teyssières L, Lascols O, Capeau J, Vigouroux C. What the Genetics of Lipodystrophy Can Teach Us About Insulin Resistance and Diabetes. Curr Diab Rep. 2013;13(6):757-67.

3. Nolis T. Exploring the pathophysiology behind the more common genetic and acquired lipodystrophies. J Hum Genet. 2014;59(1):16-23.

4. Gavrilova O, Marcus-Samuels B, Graham D, Kim JK, Shulman Gl, Castle AL, Vinson C, Eckhaus M, Reitman ML. Surgical implantation of adipose tissue reverses diabetes in lipoatrophic mice. J Clin Invest. 2000;105(3):271-8.

5. Reitman ML, Arioglu E, Gavrilova O, Taylor SI. Lipoatrophy revisited. Trends Endocrinol Metab. 2000;11(10):410-6.

6. Abate N. Adipocyte maturation arrest: a determinant of systemic insulin resistance to glucose disposal. J Clin Endocrinol Metab. 2012;97:760-3.

7. Handelsman Y, Oral EA, Bloomgarden ZT, Brown RJ, Chan JL, Einhorm D, Garber AJ, Garg A, Garvey WT, Grunberger G, Henry RR, Lavin N, Tapiador $C D$, Weyer C. The Clinical Aproach to the Detection of Lypodistrophy - an AACE Consensus Statement. Endocr Pract. 2013;19(1):107-16.

8. Huang-Doran I, Sleigh A, Rochford JJ, O'Rahilly S, Savage DB. Lipodystrophy: metabolic insights from a rare disorder. J Endocrinol. 2010;207(3):245-55.

9. Jendle J, Nauck MA, Matthews DR, Frid A, Hermansen K, Düring M, Zdravkovic M, Strauss BJ, Garber AJ. LEAD-2 and LEAD-3 Study Groups. Weight loss with liraglutide, a once-daily human glucagon-like peptide-1 analogue for type 2 diabetes treatment as monotherapy or added to metformin, is primarily as a result of a reduction in fat tissue. Diabetes Obes Metab. 2009;11(12):1163-72.

10. Morano S, Romagnoli E, Filardi T, Nieddu L, Mandosi E, Fallarino M, Turinese I, Dagostino MP, Lenzi A, Carnevale V. Short-term effects of glucagon-like peptide 1 (GLP-1) receptor agonists on fat distribution in patients with type 2 diabetes mellitus: an ultrasonography study. Acta Diabetol. 2015;52(4):727-32.

11. Parlevliet ET, de Leeuw van Weenen JE, Romijn JA, Pijl H. GLP-1 treatment reduces endogenous insulin resistance via activation of central GLP-1 
receptors in mice fed a high-fat diet. Am J Physiol Endocrinol Metab. 2010;299:E318-24

12. Jinnouchi H, Sugiyama S, Yoshida A, Hieshima K, Kurinami N, Suzuki T, Miyamoto F, Kajiwara K, Matsui K, Jinnouchi T. Liraglutide, a Glucagon-Like Peptide-1 Analog, Increased Insulin Sensitivity Assessed by Hyperinsulinemic-Euglycemic Clamp Examination in Patients with Uncontrolled Type 2 Diabetes Mellitus. J Diabetes Res. 2015;2015:706416. doi:10.1155/2015/706416. 8 pages.

13. Wu H, Sui C, Xu H, Xia F, Zhai H, Zhang H, Weng W, Han B, Du S, Lu Y. The GLP-1 Analogue Exenatide Improves Hepatic and Muscle Insulin Sensitivity in Diabetic Rats: Tracer Studies in the Basal State and during Hyperinsulinemic-Euglycemic Clamp. J Diabetes Res. 2014;2014:524517. doi:10.1155/2014524517. 10

14. Vilsbøll T, Christensen M, Junker AE, Knop FK, Gluud LL. Effects of glucagonlike peptide-1 receptor agonists on weight loss: systematic review and meta-analyses of randomised controlled trials. BMJ. 2012;344:d7771.

15. Vilsbøøl T, Zdravkovic M, Le-Thi T, Krarup T, Schmitz O, Courreges JP, Verhoeven R, Buganova I, Madsbad S. Liraglutide, a long-acting human glucagon-like peptide-1 analog, given as monotherapy significantly improves glycemic control and lowers body weight without risk of hypoglycemia in patients with type 2 diabetes. Diabetes Care. 2007;30(6):1608-10.

16. Pantalone KM, Faiman C. Liraglutide Effective in the Severely InsulinResistant Patient with Type 2 Diabetes Requiring U-500 Insulin: A Case Report. Diabetes Technol Ther. 2013;15(4):342-3.

17. Jensterle $M$, Pirš $B$, Goričar K, Dolžan V, Janež A. Genetic variability in GLP-1 receptor is associated with inter-individual differences in weight lowering potential of liraglutide in obese women with PCOS: a pilot study. Eur J Clin Pharmacol. 2015:71:817-24.

\section{Submit your next manuscript to BioMed Central and we will help you at every step:}

- We accept pre-submission inquiries

- Our selector tool helps you to find the most relevant journal

- We provide round the clock customer support

- Convenient online submission

- Thorough peer review

- Inclusion in PubMed and all major indexing services

- Maximum visibility for your research

Submit your manuscript at www.biomedcentral.com/submit 